\title{
The effect of the economic crisis on the labour market for women in Mexico, 1987-2016
}

\author{
Reyna Elizabeth Rodríguez Pérez \\ and Mona Zelinda Aguilar Arredondo
}

\begin{abstract}
The goal of this study is to analyse the impact of the economic crisis in Mexico on the labour market for women. The analysis is carried out using data from the National Urban Employment Survey (ENEU) and the National Survey of Occupation and Employment (ENOE) for 1987-2016 and applying the decomposition of wage differentials technique proposed by Juhn, Murphy and Pierce (1991 and 1993). Key findings include persistent gender wage gaps in the country, albeit with a slight downward trend, explained largely by unobservable factors, with countercyclical patterns.
\end{abstract}

\section{Keywords}

Economic conditions, economic crisis, employment, women, labour market, women's employment, wages, gender-based discrimination, wage surveys, employment statistics, Mexico

JEL classification

J1, J16, D63

Author

Reyna Elizabeth Rodríguez Pérez is a Doctor of Science and full-time Lecturer and Researcher at the Faculty of Economics of the Autonomous University of Coahuila (Mexico). Email: reynarodriguez@uadec.edu.mx.

Mona Zelinda Aguilar Arredondo is an undergraduate in Economics of the Faculty of Economics of the Autonomous University of Coahuila (Mexico). Email: zelindaaguilar@uadec.edu.mx. 


\section{Introduction}

Globally, gender inequality persists in most economic and social areas. Within the labour market in particular, men and women have different work opportunities. According to information published by the International Labour Organization (ILO, 2016b), gender inequality in terms of labour participation has only decreased 0.6 percentage points in the last 25 years worldwide and Mexico is no exception to this trend.

In Mexico, the labour force participation rate differs from one group to the other: in the second quarter of 2016, according to the National Women's Institute (2017), it was 43.4\% for women, whereas for men it was $77.6 \%$. In addition, the gender wage gap is $18 \%$ to the detriment of women, which, according to the Organization for Economic Cooperation and Development (OECD) and the National Women's Institute (OECD, 2017), puts Mexico above average for OECD members. This is explained by factors such as education, discrimination or occupational segregation, which affect income distribution.

Furthermore, the changes caused by globalization either accentuate or reduce gender inequalities, depending on the point in the business cycle. In fact, Sánchez, Salas and Nupia (2003) state that the same business cycle can affect men and women differently. This is because, as Murillo and Simón (2014) note, each group may have different interactions within the labour market. Therefore, economic fluctuations affect the labour market differently for men and women.

A number of theories and hypotheses attempt to explain the gender wage gap and its relationship with the business cycle. For example, Park and Shin (2005) affirm that the gender wage gap behaves procyclically, as it tends to narrow in recessions and widen during expansions. In addition, Stephens (2002) explains that in recessions, more women join the labour market in response to declines in family income, owing to rises in male unemployment, producing the "added worker" effect. However, Rubery (1988) challenges this view, stating that women act as a flexible reserve that is indispensable in recessions, unlike men.

Some studies have addressed this issue. At the international level, Sabogal (2012) observed that the gender wage gap in Colombia behaves procyclically. Piazzalunga and Di Tomasso (2016) find the opposite to be true for Italy, since the labour structure of the country is different. Meanwhile, for Mexico, Freije, López-Acevedo and Rodríguez-Oreggia (2011) identify declines in inequality during contractions that vary according to economic sector and region of the country.

In turn, Castro, Rodríguez and Brown (2018) and Rodríguez and Germán-Soto (2021), find for Mexico procyclical behaviour of the gender wage gap, although their results vary by region and economic sector. However, the empirical literature for Mexico does not seek more detailed results for comparative periods, and there is a scarcity of studies that cover a larger portion of the business cycle in the country.

In this regard, this study will focus on investigating whether the gender wage gap in Mexico behaves in a procyclical (positive) or countercyclical (negative) manner during expansions and recessions. This raises certain questions: how does the wage gap behave during different economic booms and recessions? Do more women join the labour market during recessions? Is the gender wage gap explained to a greater extent by unobservable factors?

The goal of this study is to analyse the impact of economic crises in Mexico on the labour market for women. For the analysis, this research uses data from the National Urban Employment Survey (ENEU) and the National Survey of Occupation and Employment (ENOE) for 1987-2016 and the decomposition of wage differentials technique proposed by Juhn, Murphy and Pierce (1991 and 1993), which enables measurement of changes in wage gaps over certain periods of time and the determination of explanatory variables in terms of productive characteristics $(\mathrm{Q})$ and wages $(\mathrm{P})$. 
The hypothesis to be tested is that the gender wage gap tends to narrow in recessions and widen in expansions. As previously mentioned, this may be caused by more women joining the labour market during recessions, as a response to decreases in household income because of increased unemployment of men.

One of the key results shows that the gender wage gap persists in Mexico, and follows a countercyclical pattern. By verifying that many of the unobservable factors represent important explanatory elements, it is clear that the endowment of productive characteristics for women is not matched by their wages in the labour market.

This article is composed of six sections besides the introduction. In the second section, there is a review of the literature on the subject, which addresses the concepts of wage inequality and business cycles and examines some empirical studies. The third section characterizes the labour market for women in Mexico and the fourth provides some economic context. The fifth section presents the data and methodology. The sixth section presents the results of the decomposition of wage differentials carried out using the method proposed by Juhn, Murphy and Pierce (1991 and 1993) and the seventh presents the conclusions of the study.

\section{The literature and concepts}

\section{Gender wage gaps}

Women have not entered the labour market on an equal footing with men, owing to issues such as professional training, time spent on production activities and even social stereotypes. In this respect, it is very important to examine the meaning of inequality.

According to Antón (2015), in the field of social sciences, inequality is a comparative concept. It is defined as the existence of differences in opportunities, access, possession, control and enjoyment of resources and power, arising from differences in individuals' conditions, situations and experiences. Antón (2014) affirms that inequality refers to social relations of advantages or privileges as opposed to disadvantages or discrimination, and also includes patterns of domination, exploitation and oppression of certain segments or levels of society by other groups within society, by means of mechanisms of subordination and subjugation. Inequality can take a variety of forms. It can appear in any social, educational or work environment or by gender. In the case of employment, wage inequality can be related to the different remuneration that workers receive in an occupation.

The Global Wage Report 2016/17 (ILO, 2016a) states that the gender pay gap is the percentage shortfall in the average wage of women, relative to the average wage of men. Gender wage inequality is therefore expressed as this gender pay gap or gender wage gap. It is important to clarify the point, as this research focuses on the widening and narrowing of the gender wage gap. Any discrimination or segregation that may be identified will be considered potential causes of the gap. A dynamic vision must also be employed in the analysis, as the behaviour of the gap is not necessarily set in stone. In fact, the wage gap may vary from one period to the next.

\section{Business cycles and wage inequality}

Understanding patterns in economic activity is crucial to explaining an economy's development and growth over time. However, equilibrium and positive performance of economic activity are by no means permanent. In fact, they are determined by repetitive behaviours that tend to occur periodically and cause fluctuations in all macroeconomic variables. These periods are normally known as business cycles. 
Samuelson and Nordhaus (2005) describe business cycles as economy-wide fluctuations in output, income and employment, usually lasting 2 to 10 years. The length of business cycles has always been a matter of discussion among researchers. Three types of cycles can be distinguished: short, medium and long.

These different cycles can put an economy in various situations that can lead to specific wage patterns. In the economic literature two viewpoints can be found regarding wage patterns in business cycles. According to Mankiw (2009), the position of Keynes, one of the most influential exponents on the subject, is that wages follow a rigid downward pattern, and adjust relatively slowly even if there is economic change, or do not adjust at all. In contrast, the classic position suggests that wages readjust when new conditions arise in the market, meaning that they are flexible.

Interestingly, these theories on wage patterns do not take into account any distinctions between workers. Although either may be closer to the truth, how wages are allocated to groups in terms of gender may follow an entirely opposite pattern. In fact, according to Sánchez, Salas and Nupia (2003), the business cycle affects men and women differently, so dissimilar effects on variations in their wages should be expected. According to Murillo and Simón (2014), this is because the two sexes have different characteristics, and interact in different ways in the labour market.

For example, as regards recessions and crises, authors such as Stephens (2002) argue that in those periods a gradual inclusion of more women in the labour market should be observed, as falls in family income caused by lower male participation lead to greater female participation to offset lost purchasing power, giving rise to the "added worker" effect. To some degree, a more pronounced wage gap in favour of men can be expected to be seen, since, as a result of households' strategy in response to temporary drops in income, women join the labour force. Conversely, during booms women's participation would be expected to be lower than men's.

However, not all authors agree with this idea. For example, Goodman, Antczak and Freeman (1993) dispute this theory. They state that in the downturns there is less loss of female employment, but this is because the contractionary period of the cycle affects male-dominated sectors. This means that the labour segregation of women into certain sectors has a positive effect in such periods; however, this does not mean that women receive higher wages.

With respect to expansive phases, from a feminist standpoint, Rubery (1988) affirms that women can act as a flexible reserve or buffer that joins the labour market in periods of growth and is dispensable in recessions, meaning that female employment behaves procyclically and real wages tend to decline for women during booms. In a hypothesis that falls within the Marxist feminist vision, Milkman (1976) asserts that perpetuation of gender roles plays a crucial role in this model: women's unemployment is considered flexible and interchangeable for domestic work, unlike men's work.

In short, there is a multitude of theoretical proposals regarding the gender-related aspects of wage distribution and business cycles. Therefore, the scope of the described theories must be specified, in order to provide different hypotheses. These hypotheses will be contrasted in this research, to demonstrate how the gender wage gap behaves in expansions and contractions. Particular attention will be paid to the "added worker" theory, which relates to increased participation by women in the labour market, to compensate for loss of household income. However, examining different hypotheses will give a better picture and enrich the research.

\section{Empirical studies}

There are almost no empirical studies that seek to describe the behaviour of the gender wage gap during economic expansions or recessions in Mexico. Very few authors have addressed the relationship between these topics. However, certain studies have provided some input for analysis of the gender wage gap. 
The research of Esquivel and Rodríguez (2003) is one study that does not focus on examining business cycles, but which was able to provide an overview of the gap in a given period. The study examines the period from 1988 to 2000. It finds an increase in the wage gaps for skilled and unskilled workers. To some degree, it confirms human capital theory, and considers specialization of workers to be an important contributing factor to the gap. Moreover, it is assumed that conclusive evidence of this can be found in the widening of the wage gap following the entry into force of treaties to liberalize the economy, overlapping several times with recessions in the Mexican economy. Although the gender wage gap was not examined in the study, Meza González (2001) analyses the same period and finds, paradoxically, empirical information that confirms that before 1996 the wage gap for the entire country increased, but the gender gap decreased. The author explains this phenomenon on the basis of factors such as an increase in women's participation in the labour market and an increase in their educational level.

Campos-Vázquez, Esquivel and Lustig (2014) conducted a follow-up to the study by Esquivel and Rodríguez (2003), in the form of an extension, covering the period from 1989 to 2010. Their research uses the Oaxaca-Blinder methodology and a decomposition of the Gini coefficient. As in the previous case, they observed a significant increase in the wage gap in the first period up to 2000 , and a percentage reduction thereafter. The explanation lies in the relationship between the labour market and trade liberalization and certain policies that were implemented, such as the North American Free Trade Agreement (NAFTA). This work also underscores the importance of the production capacities that are needed for the new labour structure, which caused the gap to increase at first and then start to decrease. However, this study does not apply the gender perspective in its analysis. To date, no research has attempted to incorporate a gender perspective into the work of Campos-Vázquez, Esquivel and Lustig (2014); nonetheless it remains important to understand the behaviour of the overall gap, to enable later comparisons.

One study that addresses the three issues mentioned (wage gap, gender and economic crises) is the one carried out by Skoufias and Parker (2006). Their work addresses the behaviour of households during Mexico's 1995 peso crisis. Using a panel method, it finds an "added worker" effect that tends to increase women's participation in the labour market when unfavourable environments emerge. However, it is not clear what the income differential between men and women is Popli (2008) complements this information with data from a period after the crisis. Her study showed that, after the 1994 recession, the gender wage gap varied according to whether work was formal or informal. In particular, the gap increased in favour of formal jobs. In addition, overall, the gender wage gap narrowed in the period from 1996 to 2006. This, according to Popli, could be explained by the differences between the economic sectors in which men and women tend to work.

Another study that focuses on how business cycles affect the gender wage gap is that of Freije, López-Acevedo and Rodríguez-Oreggia (2011). Using econometric regressions, the research studies different periods, from 2007 to 2010 . The result of the analysis is that, overall, the wage gap is systematically decreasing in this phase of 2007 to 2010. The explanation includes several factors. Firstly, they point to geographical location, which is to say how each region was affected differently by the 2008 crisis. Sectors of activity can also be an important factor; for example, manufacturing was the hardest hit during the economic downturn.

Castro, Rodríguez and Brown (2018) conducted a study for the states on the northern border of Mexico, with data from the 2005, 2009 and 2013 National Survey of Occupation and Employment (ENOE), applying the methodology of DiNardo, Fortin and Lemieux (1996). The results indicate that for three different points in time, including 2009 (a year marked by a recession), the gender wage gap shows a downward trend, characterized by a relative fall in men's real hourly wage during the crisis and a continuation in subsequent years. Thus, during the 2005-2013 period, the gender wage gap was indeed affected by the economic environment, especially during the recession, which seems to indicate procyclical behaviour, since it narrowed when economic activity contracted, but no increase in the wage gap is observed during the expansion. 
In a more recent study, Rodríguez and Germán-Soto (2021) analyse the cyclical relationship of wages and the gender wage gap with six macroeconomic variables of the Mexican manufacturing sector from January 1993 to March 2017. Their hypothesis suggests that the wage gap narrows in recessions and widens during the expansionary phase of the cycle (procyclical). The methodology used is the Hodrick-Prescott filter (Hodrick and Prescott, 1997), with which they measure the cycle, and the Oaxaca-Blinder methodology, with which they estimate the wage gap. The data they use are from the National Urban Employment Survey (ENEU, 1993-2004) and the National Occupation and Employment Survey (ENOE, 2005-2017). The results they obtain indicate that wages and wage gaps are procyclical with respect to production, investment, exports and unit costs, but are more volatile and undergo longer-lasting fluctuations. Moreover, they are countercyclical with respect to labour productivity and inflation.

Lastly, the limited conclusive information available confirms the assumptions of human capital theory. The wage gap is not always explained by the same productive characteristics of men and women. As evidence of this, a number of researchers have concluded that education is not generally an explanatory variable for wage differences. But valuable information has been collected on other variables to be considered. Some of them suggest phenomena such as occupational discrimination or segregation, which could explain gender pay inequalities more eloquently. Other authors have highlighted more specific factors, to understand the cause of such differentials. The region in which the economy is located and structural conditions over time have contributed to income potentially undergoing different variations. Other more specific factors also have an impact on worker productivity, such as experience.

It should also be noted that, in the case of Mexico, the empirical information found from 2003 to 2011 for studying the gender wage gap that compares different periods of time, focuses only on a specific phase or on random periods of time, not covering a business cycle as such. Recently, from 2018 to 2021, the evidence indicates that there is a narrowing of the gender wage gap during contraction phases, which varies by sector and region, and its behaviour has been procyclical. Therefore, there is an opportunity to continue to research and make new contributions to the subject. This empirical gap allows us to focus on a comparative analysis of economic booms and recessions. As a starting point, the macroeconomic context will first be examined, forming a firm foundation for the research.

\section{Labour market conditions and women's inclusion in the market}

The Mexican labour market has undergone different transformations. The increase in female labour participation since the beginning of the century twentieth, can be explained by market development, technical transformations at work and changes in social customs.

It was from 1930 onward, with the shift to an inward-oriented industrialization model, that the social and labour structure in Mexico began to change, causing diversification into different occupational opportunities for men and women; for example, service activities initially performed by women gradually became more male-dominated. Similarly, the expansion of the education system, health services, commerce and office work created more employment opportunities for women, although domestic service persisted (Brown and Domínguez, 2010).

It was not until 1950 when, according to these same authors, an upward phase of the accumulation cycle began, marking the start of a process of tertiarization of employment in the country. Agricultural activities, which accounted for $60 \%$ of employment at the beginning of the twentieth century but declined steadily to just $13 \%$ in 2015 , were left behind and the tertiary sector increased in importance, with its employment increasing from $16 \%$ to $61 \%$ in the same period. 
During this same phase of stabilization, from 1950 to 1980, there was an increase in women's participation in the labour force, which, according to Hernández Licona (2000) grew at a rate of $64 \%$, while for men participation decreased by $23 \%$. Table 1 shows a continuous increase in the labour force participation of women during this period and a slight decrease for men, confirming the aforementioned pattern.

Table 1

Mexico: labour force participation rate by sex, 1950-2015

(Percentages)

\begin{tabular}{llll}
\hline Year & Total & Men & Women \\
\hline 1950 & 49.5 & 88.2 & 13.1 \\
\hline 1960 & 46.5 & 78.7 & 15.4 \\
\hline 1970 & 44.9 & 73.0 & 17.6 \\
\hline 1979 & 45.7 & 71.3 & 21.5 \\
\hline 1991 & 53.6 & 77.7 & 31.5 \\
\hline 1995 & 55.6 & 78.2 & 34.5 \\
\hline 2000 & 57.8 & 79.5 & 38.3 \\
\hline 2005 & 59.7 & 80.4 & 41.6 \\
\hline 2010 & 59.0 & 78.1 & 41.7 \\
\hline 2015 & 60.0 & 78.2 & 44.3 \\
\hline
\end{tabular}

Source: Secretariat of Economic Affairs, Séptimo Censo General de Población, 6 de junio de 1950: resumen general, Mexico City, 1953; Secretariat of Industry and Commerce, IX Censo General de Población, 1970, 28 de enero de 1970: resumen general, Mexico City, 1972; O. Altimir, "La medición de la población económicamente activa de México: 1950-1970", Estudios Demográficos y Urbanos, vol. 8, No. 1, Mexico City, El Colegio de México, 1974; Secretariat of Programming and the Budget (SPP), Encuesta Continua sobre Ocupación, series 1, vol. 7, Mexico City, 1980; National Institute of Statistics and Geography (INEGI)/Secretariat of Labour and Social Security, Encuesta Nacional de Empleo 1991, Aguascalientes, 1993; National Institute of Statistics and Geography (INEGI)/Secretariat of Labour and Social Security, Encuesta Nacional de Empleo: edición 1995, Aguascalientes, 1996; National Institute of Statistics and Geography (INEGI)/Secretariat of Labour and Social Security, Encuesta Nacional de Empleo 2000, Aguascalientes, 2001; National Institute of Statistics and Geography (INEGI)/Secretariat of Labour and Social Security, Encuesta Nacional de Ocupación y Empleo 2005, Aguascalientes, 2005; National Institute of Statistics and Geography (INEGI)/Secretariat of Labour and Social Security, Encuesta Nacional de Ocupación y Empleo ENOE 2010, Aguascalientes, 2011; National Institute of Statistics and Geography (INEGI), "Encuesta Nacional de Ocupación y Empleo 2015", 2018 [online] https://www.lo.org/surveyLib/ index.php/catalog/1859/related-materials.

The increase in female labour force participation during this phase is explained by different factors. Brown and Domínguez (2010) highlight the emerging diversification of the productive fabric during those years. This occurred since the increase in the service sector benefited occupations that were considered socially "suited for women". Furthermore, as mentioned by Rojas-Gómez and Sotelo Peralta (2003), during this same period, equal rights and duties became consolidated for both sexes, supported by the Mexican Constitution, resulting in greater employment benefits and wider access to political participation for women. Although attitudes concerning the activities that women were expected to perform remained antiquated, these changes laid the foundations for the inclusion of women.

The change in the economic panorama at the beginning of the 1980s further increased the labour participation of women, which rose from $21.5 \%$ in 1979 to $31.5 \%$ in 1991 , while the rate for men rose from $71.3 \%$ to $77.7 \%$ (see table 1). This is contrary to what might be expected, owing to the different crises that occurred during this period. However, according to Hernández Licona (2000), this increase in women's participation along with that of men may be explained by the crises that forced families and individuals to redouble their work efforts.

The processes of productive restructuring that began in the 1980s were not necessarily accompanied by job creation. Although the participation rate increased, the proportion of women in the economically active population decreased between 1980 and 1991 from $27.8 \%$ to $23.5 \%$, as shown in table 2. It was 
not until the further productive restructuring took place in the 1990s that labour dynamics for women improved. As the economy became outward-oriented, the sectors that produced for the internal market were notably abandoned to sell products in the international market (Balderas Arrieta, 2006).

Table 2

Mexico: economically active population, by sex, annual series 1980-2015

(Numbers and percentages)

\begin{tabular}{lccccc}
\hline & Total & Men & $\begin{array}{c}\text { Rate } \\
\text { (percentages) }\end{array}$ & Women & $\begin{array}{c}\text { Rate } \\
\text { (percentages) }\end{array}$ \\
\hline 1980 & 22066084 & 15924806 & 72.17 & 6141278 & 27.83 \\
\hline 1991 & 24063283 & 18418695 & 76.54 & 5644588 & 23.46 \\
\hline 2000 & 40161543 & 26418355 & 65.78 & 13743188 & 34.22 \\
\hline 2005 & 42863703 & 26993388 & 62.97 & 15870315 & 37.03 \\
\hline 2010 & 45911934 & 28768675 & 62.66 & 17143259 & 37.34 \\
\hline
\end{tabular}

Source: Prepared by the authors, on the basis of Secretariat of Programming and the Budget (SPP), Información sobre ocupación, No. 11, trimester 1, Mexico City, 1980; National Institute of Statistics and Geography (INEGI)/Secretariat of Labour and Social Security, Encuesta Nacional de Empleo 1991, Aguascalientes, 1993; National Institute of Statistics and Geography (INEGI)/Secretariat of Labour and Social Security, Encuesta Nacional de Empleo 2000, Aguascalientes, 2001; National Institute of Statistics and Geography (INEGI)/Secretariat of Labour and Social Security, Encuesta Nacional de Ocupación y Empleo 2005, Aguascalientes, 2005; National Institute of Statistics and Geography (INEGI)/Secretariat of Labour and Social Security, Encuesta Nacional de Ocupación y Empleo ENOE 2010, Aguascalientes, 2011; National Institute of Statistics and Geography (INEGI), "Encuesta Nacional de Ocupación y Empleo 2015", 2018 [online] https://www.ilo.org/ surveyLib/index.php/catalog/1859/related-materials.

Note: The information refers to the population aged 15 and over (for 2005, 2010 and 2015), according to the National Survey of Occupation and Employment (ENOE), and to the population aged 12 and over, according to Información sobre ocupación (1980) and the National Employment Survey (for 1991 and 2000).

Thus, employment became concentrated in an export structure based on products from the automotive and maquiladora sectors and oil, according to Balderas Arrieta (2006). Rendón and Maldonado (2005) state that this increase in industrial employment benefited women in particular. In addition, the commerce and service sectors, which expanded more, account for some of the main employment activities of women. Table 2 shows an increase in the proportion of women in the economically active population, from $23.5 \%$ in 1991 to $34.2 \%$ in 2000 . Table 3 confirms that the industrial and tertiary sectors have been the most favoured, accounting for the majority of the employed population, both female and male. In the tertiary sector, the fastest growing sector, the number of women in employment increased from 6.46 million in 1991 to 15.63 million in 2015. These figures show how female employment in this sector was 2.41 times higher by 2015.

Overall, evidence has been provided that participation by women in the labour market in Mexico has increased and is continuing to do so. However, this does not mean that the wages women receive are converging with men's. In fact, a significant wage gap still exists, which is the subject of this research.

Some authors attribute this wage inequality to the occupational positioning of each sex. Many women are employed in segments with lower wages, according to Macías Vázquez (1990). However, other authors argue that the gap may vary according to other factors, including marital status and working hours. What is clear is that wage gaps have behaved differently in different time periods. Therefore, in continuing the analysis of the context, is essential to focus attention on output patterns and the main phases of national contraction and expansion. 
Table 3

Mexico: employed population, by sex and sector of economic activity, 1991-2015 (Thousands of persons employed)

\begin{tabular}{|c|c|c|c|c|c|c|}
\hline Year & Sex & Total & Primary & Secondary & Tertiary & Not specified \\
\hline \multirow{3}{*}{1991} & Total & 30534.1 & 8189.8 & 7046.4 & 15112.5 & 185.4 \\
\hline & Men & 21256.9 & 7185.9 & 5271.4 & 8647.7 & 151.8 \\
\hline & Women & 9277.2 & 1003.8 & 1774.9 & 6464.8 & 33.6 \\
\hline \multirow{3}{*}{2000} & Total & 39502.2 & 7129.6 & 10568.5 & 21640.0 & 164.0 \\
\hline & Men & 26011.2 & 6158.4 & 7579.7 & 12146.6 & 126.5 \\
\hline & Women & 13490.9 & 971.2 & 2988.8 & 9493.4 & 37.5 \\
\hline \multirow{3}{*}{2005} & Total & 40791.8 & 6059.8 & 10405.8 & 24078.0 & 248.2 \\
\hline & Men & 25853.1 & 5332.4 & 7599.8 & 12749.4 & 171.4 \\
\hline & Women & 14938.7 & 727.4 & 2806.0 & 11328.5 & 76.8 \\
\hline \multirow{3}{*}{2010} & Total & 45911.9 & 6530.7 & 10943.8 & 28137.6 & 299.8 \\
\hline & Men & 28768.7 & 5805.7 & 8172.0 & 14595.1 & 195.9 \\
\hline & Women & 17143.3 & 725.0 & 2771.8 & 13542.6 & 103.9 \\
\hline \multirow{3}{*}{2015} & Total & 51568.5 & 6896.0 & 12743.2 & 31628.1 & 301.2 \\
\hline & Men & 31757.8 & 6092.7 & 9452.9 & 16002.5 & 209.7 \\
\hline & Women & 19810.7 & 803.2 & 3290.3 & 15625.6 & 91.6 \\
\hline
\end{tabular}

Source: National Institute of Statistics and Geography (INEGI)/Secretariat of Labour and Social Security, Encuesta Nacional de Empleo 1991, Aguascalientes, 1993; National Institute of Statistics and Geography (INEGI)/Secretariat of Labour and Social Security, Encuesta Nacional de Empleo 2000, Aguascalientes, 2001; National Institute of Statistics and Geography (INEGI)/ Secretariat of Labour and Social Security, Encuesta Nacional de Ocupación y Empleo 2005, Aguascalientes, 2005; National Institute of Statistics and Geography (INEGI)/Secretariat of Labour and Social Security, Encuesta Nacional de Ocupación y Empleo ENOE 2010, Aguascalientes, 2011; National Institute of Statistics and Geography (INEGI), "Encuesta Nacional de Ocupación y Empleo 2015", 2018 [online] https://www.lo.org/surveyLib/index.php/catalog/1859/related-materials.

Note: Information for the second quarter of each year. Refers to the population aged 14 and over.

\section{Economic patterns and the main phases of the economy in Mexico}

Economic activity in Mexico has been characterized by a number of distinct periods of variations. Describing these trends will give insight into the overall trend to then be able to focus on the booms and recessions that Mexico has experienced.

Gollás (2003) identifies a dramatic change from the 1970s onwards, linked to inward-oriented development policies. Populist rhetoric, private sector uncertainty and government overspending prevented sustained economic growth, which in previous years was around 6\%.

From approximately 1980 onward, Mexico's economic performance became unstable. Volatility became more frequent, and has persisted from the 1980s to the present. Figure 1, based on World Bank data, shows annual GDP growth rates in the Mexican business cycle that ran from 1980 to 2016.

The data show successive slowdowns during the period. Many, like Velázquez Orihuela and Vargas Sánchez (2014), attribute the volatility from the 1980s onward to policies that were formulated to open the economy to the external market, but which shrank the domestic market. The reality is that a fragile economy and huge fiscal and monetary imbalances, resulting from mismanagement of previous governments, made a paradigm shift necessary to stimulate economic spillover. Thus, it was during this period that the economy was opened up to trade, a process that is considered a milestone in terms of understanding the patterns in economic fluctuations. 
Figure 1

Mexico: gross domestic product (GDP) growth, 1980-2016

(Percentages)

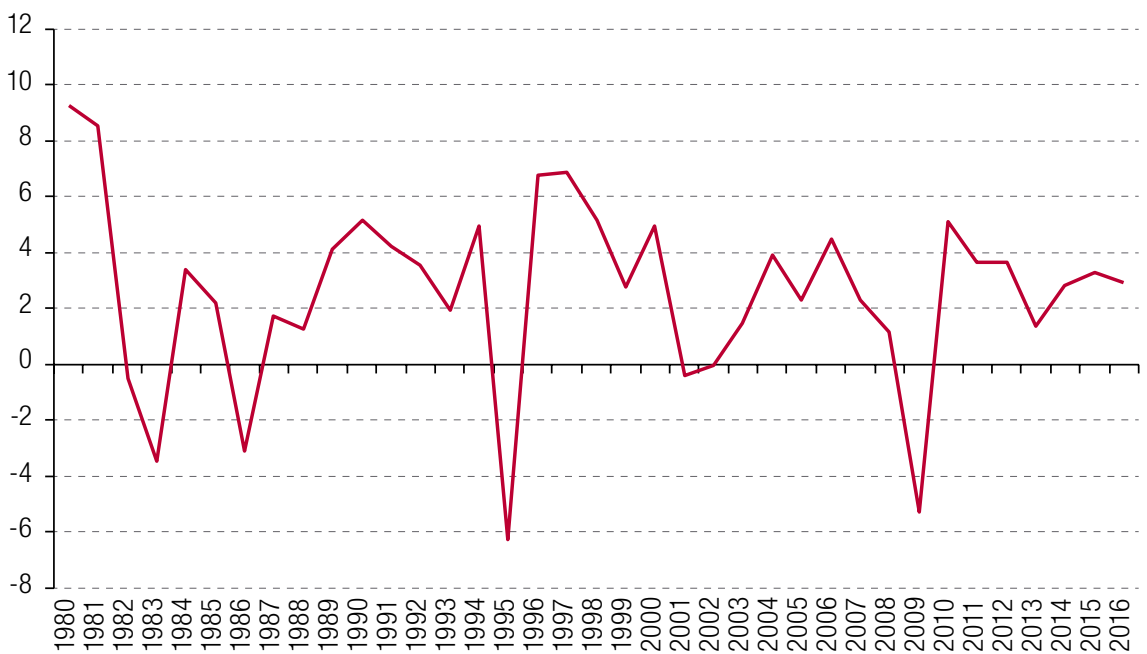

Source: Prepared by the authors, on the basis of World Bank, "GDP growth (annual \%) - Mexico", 2019 [online] https://data. worldbank.org/indicator/NY.GDP.MKTP.KD.ZG?locations=MX.

Regarding the structure of the cycle, Loría and Salas (2014) define a business cycle as the passage from one peak to another. In their study of the period from 1980 to 2013, they identify six clear cycles, as listed in table 4: 1981-1985, 1985-1994, 1994-1998, 1998-2000 and 2000-2013.

Table 4

Mexico: occurrence and duration of peak-to-peak cycles, 1980-2013

(Quarters)

\begin{tabular}{lc}
\hline Period & Duration in quarters \\
\hline $1981-1985$ & 15 \\
\hline $1985-1994$ & 36 \\
\hline $1994-1998$ & 14 \\
\hline $1998-2000$ & 9 \\
\hline $2000-2008$ & 32 \\
\hline $2008-2013$ & 22 \\
\hline
\end{tabular}

Source: E. Loría and E. Salas, "Ciclos, crecimiento económico y crisis en México, 1980. 1-2013.4", Estudios Económicos, vol. 29, No. 2, 2014.

Loría and Salas also state that the cycles occurred during this period every three to five years. With respect to amplitude, they identify peaks in expansion as a percentage of potential GDP, the first being around $4 \%$, with clearly smaller movements than before the 1980s. The authors specify two types of troughs: larger ones of $-6.29 \%$ in 1995 and of $-5.28 \%$ in 2009, and smaller ones in 1983 and 1986 of $-3.48 \%$ and $-3.07 \%$, respectively.

The results show a short business cycle for Mexico, with six key troughs, reflecting the major economic crises in the country. Although the research of these authors does not completely encompass the period covered by this study, it does include the main slowdowns that are to be considered. In fact, this study will continue by focusing on just four of the six cycles corresponding to the period of analysis (1987-2016). The analysis will take 1987, 1995, 2001, 2009 and 2016 as troughs, and 1990, 1997, 2006 and 2012 as peaks of the cycles. 


\section{Main critical points of the economic cycles}

As mentioned above, a series of GDP fluctuations began in the 1980 s and have continued through to the present day. Two turning points in this decade were part of the 1981-1985 and 1985-1994 cycles. However, since the availability of data is limited to the information published by the National Institute of Statistics and Geography (INEGI), which begins in 1987, the explanation of the main critical phases will begin with the 1986 crisis. In addition, to provide some background, the major crises will be described, in order to contrast them with the peaks. To begin providing the context of the Mexican economic crises, we will draw on national and international history, to give an overview of the events.

After the Second World War, some countries introduced a new approach known as the import substitution model, as the most practicable strategy to respond to the external shock. In Mexico, this meant inward-oriented industrialization, justifying protectionism by the State, and encouraging domestic production, mainly in manufacturing, substituting foreign goods.

This initially led to the country entering a period of expansion in the 1950s, which continued through to the 1980s. However, different internal and external effects started to contribute significantly to the deterioration of the model (Aviña Montiel, 2014). Rural labour began to move to urban areas, leading to a change in the labour market, characterized by unemployment and low wages. In addition, subsidies, expansions of infrastructure and the nationalization of companies resulted in public overspending, which was financed with external loans.

In the 1970s this process became even more pronounced. However, the oil boom came, creating a "utopian mirage", with disproportionate growth expectations for the economy. This encouraged further neglect of public finances and fiscal mismanagement. This was reflected most clearly in growth in foreign debt, which rose from just US\$ 4.263 billion at the end of 1970, equivalent to $12 \%$ of GDP, to US\$ 19.600 billion at the end of 1976, equivalent to 35\% of GDP, according to Reyes-Heroles and Suárez Dávila (2009). This economic instability reached a crescendo in the early 1980s, when price rises, an imbalanced current account and the financing of public expenditure with foreign debt became unsustainable.

The first crisis of the 1980s erupted in 1982. Public debt grew as never before. In addition, towards the end of the López Portillo administration, radical measures were taken, such as nationalizing the banking system, further fuelling distrust in the business sector. Inevitably, there was a capital flight, which led to implementation of measures early in the presidency of Miguel de la Madrid, including policies to rein in wages, sizeable spending cuts and the beginning of an opening up of trade to encourage fresh private investment in the country. The 1982 crisis caused severe stagnation, austerity and inflation, which was brought under control with the first measures and agreements implemented by the new government. However, this stability was again undermined when oil prices hit a low.

As a result, an aftershock of the 1982 crisis came in 1986. The temporary stability evaporated, and the country underwent an abrupt economic slowdown (Lustig, 1998). In this crisis, GDP fell 3.07\%. With the country's subsequent inability to meet financial obligations, the situation became even more difficult. In addition, the sharp drop in oil prices, the persistent fiscal deficit and above all an inability to pay debts led to the shock being absorbed entirely at the domestic level. The measures were severe, with even more restrictive policy, continued exchange rate devaluation and accelerated liberalization of trade. At the end of the year, in order to prevent the sharp fall in GDP from affecting foreign trade relations, emergency measures were implemented, as recommended by international institutions. Also, with the Baker Plan, which was introduced with the cooperation of the United States, Mexico obtained more financing, and the economy began to recover (Damm and Gutiérrez, 2005). In addition, economic liberalization was resumed with greater determination. 
These measures seemed to produce results in the subsequent years, as GDP entered into a recovery that lasted until 1990, when GDP growth peaked. This growth in GDP, which reached 5\%, is shown in figure 1. However, structural problems remained, and not merely those typical of developing countries, according to Reyes-Heroles and Suárez-Dávila (2009).

The combination of these domestic problems, an ongoing imbalance in the exchange rate, a persistent current account deficit and the depletion of international reserves ultimately triggered a new economic crisis, marking the end of the first business cycle.

The 1994 was the year of the most severe financial crisis the country has experienced. One year after the North American Free Trade Agreement (NAFTA) was signed, the national economy underwent an unparalleled collapse, which was the most severe crisis of that business cycle, with a massive capital flight owing to volatility and the economic outlook. The buoyancy seen in the economy was lost and GDP fell by 6\% in 1995 (Reyes-Heroles and Suárez Dávila, 2009). This eroded standards of living and brought disproportionate inflation and a considerable increase in poverty. One of the measures taken to promote recovery was a free-floating exchange rate. In addition, a rescue package was made available by international institutions to prevent the crisis spreading internationally. A fresh restoration of economic stability thus began, lasting three years, until the pace of economic growth was again brisk. This peak was one of the highest in the period covered by this study, with a growth rate of close to 7\% in 1997 (see figure 1). However, in the five subsequent years, GDP contracted.

However, a new slowdown hit the Mexican economy, in a context of global uncertainty on stock markets, mainly owing to a recession in the United States, a slowdown in Asia and political instability in Latin America, according to Banco de México (2002). In 2001, there was another economic crisis, although this slowdown had one of the smallest impacts, as GDP declined by $0.4 \%$ (see figure 1 ). Moreover, it coincided with the market entry of new emerging economies, which directly affected the Mexican economy's exports, and the spread of the crisis from the United States led to a severe drop in direct investment and a decrease in remittances. However, steps were quickly implemented by the United States to support the recovery from the ongoing global recession. Thus, over the following years there was a steady recovery until a peak was reached in 2006, when Mexico's GDP grew at a rate of almost $5 \%$.

This phase did not last long, because in 2008 there was again one of the worst economic contractions, a global financial crisis, caused by a boom in lending by the different Federal Reserve Banks of the United States to finance mortgages in the country, fuelling a financial bubble so large that the fallout was worldwide. Globalization and the close relationship that had grown between Mexico and the United States over the previous decades meant that the crisis instantly spread to Mexico, with an immediate impact. In addition, because commodity prices were affected, oil prices once again contributed to a weakening of economic growth. According to World Bank (2019) data (see figure 1), GDP contracted by $5.28 \%$ in 2009. Furthermore, according to Damián (2012), unemployment increased by almost $6 \%$, so a fall in income was one of the main features of the crisis. The economy later recovered. In fact, OECD (2011) confirmed that the Mexican economy recorded a strong recovery in 2011 after the crisis, returning to almost the same levels in the indicators that had deteriorated because of the slowdown. In 2012, growth was also around $4 \%$ (figure 1). However, the subsequent years have been characterized by a continued slowdown, leaving the growth rate at around 3\% in 2016.

Gender relations in the Mexican labour market have shifted in tandem with economic, demographic, social and cultural changes. To fail to include all these aspects in our analysis would bias it by attributing a single cause to the transformations. In addition, it is important to identify the main turning points, in order to follow the changes in the patterns of the gender wage gap over time. 


\section{Data and methodology}

This research combines two surveys published by INEGI that are considered suited to the 1987-2016 period studied: the National Urban Employment Survey (ENEU) for 1987-2004, and the National Survey of Occupation and Employment (ENEU) for 2005-2016. To process the microdata from the two surveys, the tables of sociodemographic, occupational and employment values for each of the years were concatenated. Specifically, for the empirical analysis, only the second quarters of each year were used, to produce a representative cross-section for the period analysed.

Also, the nature of this study requires that the focus be on people in the labour market who are in work or looking for it, the employed population being our main target population. Similarly, the focus will be on people aged 14 years or more.

The data collected in these two surveys will enable a more complete analysis, because they provide characteristics of the economically active and inactive population, their participation and working conditions, and other occupational indicators.

For monthly survey variables, the database was standardized for all years by means of two procedures. Firstly, zeros were removed for 1987-1994 (change from old to new pesos), so that the databases would match. Secondly, wage deflation was applied using August 2016 as the base date. The variable is thus expressed in real terms, allowing for a more objective and valid analysis.

The methodology proposed by Juhn, Murphy and Pierce (1991 and 1993) was used. This model allows for calculation of the exact gender wage gaps which will allow us to explain the wage differentials in economic booms and recessions. With the support of statistical data from the National Urban Employment Survey (ENEU) and the National Survey of Occupation and Employment (ENOE), information will be used on average salaries by sex, years of schooling, potential experience in the labour market and their square. The experience variable is obtained through the age of the individual and the years of formal education attained minus six, since this is the age at which the worker begins primary education. Experience squared is an approximation to the basic life-cycle model, where the concavity of the age-income profile is captured by the linear and quadratic term of experience, where diminishing returns to human capital are captured.

Thus, when applying the model, the starting point will be a Mincer equation, algebraically representing the average salary of men in the initial year, expressed as:

$$
w_{t}^{m}=\bar{X}_{t}^{m} \hat{\beta}_{t}+\sigma_{t} \bar{\theta}_{t}^{m}
$$

Where $w_{t}^{m}$ is the average hourly wage for men, expressed in logarithms; $\bar{X}_{t}^{m}$ is the mean values of the particular characteristics of men; $\hat{\beta}_{t}$ is the vector of parameters estimated jointly for males and females; $\sigma_{t}$ is the standard deviation of the wage residuals for both sexes; and $\bar{\theta}_{t}^{m}$ is the standardized average wage residuals for men. The algebraic representation for women is similar.

Thus, when formulating the wage structure of both sexes for a given year, the average salary for the sample can be expressed as:

$$
D_{t}=w_{t}^{m}-w_{t}^{f}=\left(\bar{X}_{t}^{m}-\bar{X}_{t}^{f}\right) \hat{\beta}_{t}+\left(\bar{\theta}_{t}^{m}-\bar{\theta}_{t}^{f}\right) \sigma_{t}=\Delta \bar{X}_{t} \hat{\beta}_{t}+\Delta \bar{\theta}_{t} \sigma_{t}
$$

Where the operator $\Delta$ is the average difference for both sexes with regard to the aforementioned variable and the superscripts $m$ and $f$ indicate the male and female sexes, respectively. 
In principle, equation (2) enables observation of the proportion of the gender wage gap in the initial year that is explained by differences in observable productive characteristics of men and women. It also shows the proportion of these unobservable factors that are part of the non-explanatory differentials due to productive factors. The first term resembles the standard Oaxaca-Blinder decomposition. The second term $\left(\bar{\theta}_{t}^{m}-\bar{\theta}_{t}^{f}\right) \sigma_{t}$ captures the essence of the standardized average wage residuals of the sexes, multiplied by the dispersion of the distribution of the residuals, in such a way that it is possible to observe the influence of unobservable factors on wages

Lastly, by means of certain algebraic modifications, to perform the annual comparison, the change in the gender wage gap between two different years is obtained, as follows:

$$
\begin{gathered}
D_{t}-D_{t-1}=\left(\Delta \bar{X}_{t}-\Delta \bar{X}_{t-1}\right) \hat{\beta}_{t}+\Delta \bar{X}_{t}\left(\hat{\beta}_{t}-\hat{\beta}_{t-1}\right) \\
+\left(\Delta \bar{\theta}_{t}-\Delta \bar{\theta}_{t-1}\right) \sigma_{t}+\Delta \bar{\theta}_{t}\left(\sigma_{t}-\sigma_{t-1}\right)
\end{gathered}
$$

In this regard, according to the expression in equation (3), changes in the size of the gender wage differentials between two different periods may be caused by four different factors, each of which is captured by the corresponding term of the decomposition. The first is modification of the observed productive characteristics of the sexes. The second is changes in the structure of wage differentials in the economy. The third is changes in the relative effect of unobserved factors that could bring the average wage residuals of the sexes closer together or push them further apart. The fourth is dispersion of standardized average residuals.

Of the factors mentioned above, the first and third can be said to be gender-specific characteristics, while the second and fourth are linked to general variables of the wage structure. Thus, the first two factors together correspond to the effect of factors related to observable production characteristics; and the third and fourth factors correspond to the effect of all the unexplained factors. Comparative information on cycle peaks is thus obtained.

\section{Decomposition of wage differentials according to the methodology of Juhn, Murphy and Pierce (1991 and 1993)}

Applying the methodology of Juhn, Murphy and Pierce (1991 and 1993), the decomposition of the average wage differential by gender can be observed, as well as the pattern in the analysed period of 1987-2016. The analysis will focus on two fundamental areas when applying this method: the change in the gender differential at the main critical points of the cycles, and quantifying the importance of observable and unobservable factors, in order to explain the formation of the gender wage gap.

Table 5 shows the results for the overall total of the country's economic activity. At first glance, a downward trend can be seen across the cycles in the years studied. Nevertheless, when examining the detail of fluctuations in the cycles, specific patterns are seen that differ between the periods of the highest and lowest growth rates and the periods of more moderate rates.

Thus, examining the pairs formed by 1987 and 1990 and 2001 and 2006, and considering the first year of each as the trough of the cycle and the last year as the peak, it is revealed that there are falls in the wage differential of 0.02 and 0.04 log points, respectively, reflecting less inequality during expansion than during recessions. This would be consistent with Rubery (1988), whereby women are seen as a flexible reserve during recessions. The components of the decomposition confirm the position of the gap, since, for the first sample, men's relative wages generally benefited from education and 
experience factors, favouring their pay. In contrast, for the second cycle, there was an improvement in the education-related endowments for women, although not to an extent sufficient to improve their situation with regards to the gap.

Table 5

Mexico: decomposition of the change in the average gender wage gap from the overall total of economic activity, according to the Juhn, Murphy and Pierce methodology, 1987-2016

\begin{tabular}{|c|c|c|c|c|c|c|c|c|c|}
\hline & 1987 & 1991 & 1995 & 1997 & 2001 & 2006 & 2009 & 2012 & 2016 \\
\hline Gender wage differential & -0.336 & -0.320 & -0.313 & -0.321 & -0.345 & -0.306 & -0.289 & -0.291 & -0.292 \\
\hline Observed characteristics & -0.006 & -0.010 & -0.027 & -0.025 & -0.001 & 0.0319 & 0.0378 & 0.0309 & 0.0396 \\
\hline Wage residuals & -0.330 & -0.310 & -0.286 & -0.296 & -0.344 & -0.338 & -0.327 & -0.322 & -0.332 \\
\hline Differences & & 0.0198 & 0.0071 & -0.008 & -0.023 & 0.0389 & 0.0172 & -0.001 & -0.001 \\
\hline Explained & & -0.004 & -0.016 & 0.0018 & 0.0243 & 0.0331 & 0.0059 & -0.006 & 0.0087 \\
\hline - Education & & -0.000 & 0.0025 & 0.0017 & 0.0140 & 0.0280 & -0.003 & -0.006 & 0.0018 \\
\hline - Experience & & -0.004 & -0.038 & -0.001 & 0.0211 & -0.013 & 0.0330 & 0.0119 & 0.0130 \\
\hline - Experience 2 & & 0.0010 & 0.0195 & 0.0014 & -0.010 & 0.0185 & -0.023 & -0.012 & -0.006 \\
\hline Unexplained & & 0.0241 & 0.0239 & -0.010 & -0.047 & 0.0058 & 0.0113 & 0.0051 & -0.010 \\
\hline Productive characteristics (Q) & & -0.002 & -0.007 & 0.0024 & 0.0217 & 0.0345 & 0.0070 & -0.004 & 0.0137 \\
\hline Wages (P) & & -0.001 & -0.160 & -0.000 & 0.0056 & -0.000 & -0.000 & -0.002 & -0.003 \\
\hline
\end{tabular}

Source: Prepared by the authors, on the basis of National Institute of Statistics and Geography (INEGI), "National Urban Employment Survey (ENEU)", 2005 [online databases] http://en.www.inegi.org.mx/programas/eneu/2004/?ps=microdatos; National Institute of Statistics and Geography (INEGI), Encuesta Nacional de Educación y Empleo 2006, Aguascalientes, 2007; National Institute of Statistics and Geography (INEGI), Encuesta Nacional de Ocupación y Empleo: ENOE 2009, Aguascalientes, 2010; National Institute of Statistics and Geography (INEGI), "National Survey of Occupation and Employment (ENOE), population aged 15 years and older", 2020 [online databases] http://en.www.inegi.org.mx/programas/enoe/15ymas/ default.html\#Microdata.

Note: The methodology used is presented in C. Juhn, K. Murphy and B. Pierce, "Accounting for the slowdown in black-white wage convergence", Workers and their Wages: Changing Patterns in the United States, M. Kosters (ed.), Washington, D.C., The AEI Press, 1991.

In the 1995-1997 and 2009-2012 cycles, which included the most marked crises and booms of the Mexican economy, in both cases there were quantified average increases of 0.01 log points in the wage differential. This is evidence of a widening of the wage gap to the detriment of women in booms and of a narrowing in crises.

These results coincide with those documented by Park and Shin (2005), showing procyclical behaviour by the wage gap. Moreover, the wage residuals also show an increase in the share of the wage gap attributed to unobservable factors for the first comparison of cycles, while in the second it was largely unchanged. For some authors, such as Becker (1971), this is the implicit part that reflects the existence of discrimination in the wage differential. This would suggest that greater discrimination, or other factors that are not considered, are the main reasons for the gap. In terms of explanatory variables, in the 1995-1997 and 2009-2012 cycles, the combination of factors is very favourable to women, but the unexplained part attributable to wage discrimination counteracts their effect.

In general, the information presented suggests that, for all the years, the gender wage differential is not sufficiently explained by the variables related to production characteristics, because unobservable factors actively explain the differentials.

Consolidation of all this information shows that the gender wage gap in Mexico has followed a downward trend. However, it remains unfavourable to women. Despite this, descriptive statistics show a steady increase in women's labour force participation compared to men. However, this does not change higher wages being received by men. It can therefore be assumed that the lack of productive 
characteristics endowments has maintained gender wage gaps. Nonetheless, we can see that the educational average for women has surpassed that for men. This indicates that factor endowment, in the case of Mexico, does not explain the persistent gender wage gap. Moreover, using the Juhn, Murphy and Pierce method (1991 and 1993) we can see that the gap is explained, above all, by unobservable factors, suggesting that these factors are strongly linked to wage discrimination in the labour market or to the need to consider other types of factors.

As to the overall growth in economic activity, there is no support for the theory of Park and Shin (2005), whereby the gap is expected to behave procyclically in all periods. In fact, in the cycles with smaller fluctuations, the gap behaved countercyclically, which would corroborate the theory of Rubery (1988), who hypothesized that women act as a flexible reserve during recessions.

\section{Conclusions}

A thorough analysis of the possible influence that the business cycle could have on gender wage gaps, using the decomposition of wage differentials method proposed by Juhn, Murphy and Pierce (1991 and 1993), produced results that are similar to the findings of previous research on Mexico, whereby the gender wage gap has narrowed over time (Freije, López-Acevedo y Rodríguez-Oreggia, 2011). However, unobservable factors contributed significantly to the explanation of the gap.

These results provide an overview of the Mexican labour market, revealing persistent vulnerability in the absorption and consideration of the productive characteristics of men and women. Furthermore, they demonstrate a precariousness of wages, with no increases in payment amounts in most cases, as well as a greater risk of wage loss, due to the continuous economic crises that the country has suffered.

Castro, Rodríguez and Brown (2018) and Rodríguez and Germán-Soto (2021) indicate that there is a narrowing of the gender wage gap during contraction phases, which varies by sector and region and has behaved procyclically. Likewise, in this research, no support was found for procyclical behaviour of the gap for the periods taken as a whole. Nonetheless, the periods with the lowest troughs and highest peaks did follow a pattern in line with procyclical theory. In general, this research shows, by incorporating the situational aspect of gender wage gaps, that the patterns are not static. It also shows that the reasons for wage inequality do not always lie with economic growth. Instead, they may be linked to the occupational structure in a country, and to its economic and social context.

The Sustainable Development Goals (SDGs) on poverty and employment ( 1 and 8 ) and the Goal on gender equality (goal 5), aim to find solutions for countries to reduce social and gender gaps in labour participation, improve working conditions and income, and achieve reductions in poverty. These aims can be achieved by restructuring policies and programmes to create the right incentives for labour supply and demand, taking into account the gender distribution of paid and unpaid work.

\section{Bibliography}

Antón, A. (2015), "Democracia social y desigualdad", paper presented at XI Jornadas de Pensamiento Crítico seminar, Madrid, Polytechnic University of Madrid, December.

(2014), "La desigualdad social", revised version of the paper presented at X Jornadas de Pensamiento Crítico seminar, Leganés, University Carlos III of Madrid, December 2013 [online] http://www.pensamientocritico. org/antant0114.pdf.

Aviña Montiel, N. (2014), "Los ciclos económicos de México y la crisis en la era del TLCAN”, master’s thesis, Tijuana, Colegio de la Frontera Norte.

Balderas Arrieta, I. (2006), Mujeres trabajadoras en América Latina: México, Chile y Brasil, Mexico City, Plaza y Valdés. 
Banco de México (2002), Annual Report 2001, Mexico City.

Becker, G. (1971), The Economics of Discrimination, Chicago, The University of Chicago Press.

Brown, F. and L. Domínguez (coords.) (2010), México: desigualdad económica y género, Mexico City, National Autonomous University of Mexico (UNAM).

Campos-Vázquez, R., G. Esquivel and N. Lustig (2014), "The rise and fall of income inequality in Mexico, 1989-2010", Falling Inequality in Latin America: Policy Changes and Lessons, A. Giovanni (ed.), Oxford, Oxford University Press.

Castro, D., R. Rodríguez and F. Brown (2018), "La brecha salarial por género y recesión económica en la frontera norte de México", Mercado laboral: México y frontera norte, D. Castro and R. Rodríguez (coords.), Mexico, Universidad Autónoma de Coahuila/Ediciones de Laurel.

Damián, A. (2012), "Crisis, empleo y pobreza”, La situación del trabajo en México, 2012: el trabajo en la crisis, E. De la Garza Toledo (coord.), Mexico City, Plaza y Valdés.

Damm, A. and A. Gutiérrez (coords.) (2005), Las reformas estructurales que México necesita, Mexico City, Compañía Editorial Continental (CECSA).

DiNardo, J., N. Fortin and T. Lemieux (1996), "Labor market institutions and the distribution of wages, 1973-1992: a semiparametric approach”, Econometrica, vol. 64, No. 5, September.

Esquivel, G. and J. Rodríguez (2003), "Technology, trade, and wage inequality in Mexico before and after NAFTA", Journal of Development Economics, vol. 72, No. 2.

Freije, S., G. López-Acevedo and E. Rodríguez-Oreggia (2011), "Effects of the 2008-09 economic crisis on labor markets in México", Policy Research Working Paper, No. 5840, Washington, D.C., World Bank.

Gollás, M. (2003), México: crecimiento con desigualdad y pobreza (de la sustitución de importaciones a los tratados de libre comercio con quien se deje), Mexico City, El Colegio de México.

Goodman, W., S. Antczak and L. Freeman (1993), "Women and jobs in recessions: 1969-92", Monthly Labor Review, vol. 116, No. 7.

Hernández Licona, G. (2000), "El empleo en México en el siglo XXl”, El Cotidiano, vol. 16, No. 100, Mexico City, Autonomous Metropolitan University.

Hodrick, R. and E. Prescott (1997), "Postwar U.S. business cycles: an empirical investigation", Journal of Money, Credit and Banking, vol. 29, No. 1, February.

ILO (International Labour Organization) (2016a), Global Wage Report 2016/17: Wage Inequality in the Workplace, Geneva. (2016b), Women at Work: Trends 2016, Geneva.

Juhn, C., K. Murphy and B. Pierce (1993), "Wage inequality and the rise in returns to skill", Journal of Political Economy, vol. 101, No. 3. (1991), "Accounting for the slowdown in black-white wage convergence", Workers and their Wages: Changing Patterns in the United States, M. Kosters (ed.), Washington, D.C., The AEl Press.

Loría, E. and E. Salas (2014), "Ciclos, crecimiento económico y crisis en México, 1980.1-2013.4", Estudios Económicos, vol. 29, No. 2.

Lustig, N. (1998), Mexico: the Remaking of an Economy, Washington, D.C., Brookings Institution Press.

Macías Vázquez, M. (1990), "El trabajo femenino en la industria mexicana: 1942-1984", bachelor's thesis, Mexico City, National Autonomous University of Mexico (UNAM).

Mankiw, N. (2009), Principles of Economics, Sixth Edition, Mason, South-Western Cengage Learning.

Meza González, L. (2001), "Wage inequality and the gender wage gap in Mexico", Economía Mexicana Nueva Época, vol. X, No. 2, Mexico City, Economic Research and Teaching Centre.

Milkman, R. (1976), "Women's work and economic crisis: some lessons of the Great Depression", Review of Radical Political Economics, vol. 8, No. 1.

Murillo, I. and H. Simón (2014), "La Gran Recesión y el diferencial salarial por género en España", Review of Public Economics, vol. 208, No. 1, Madrid, Institute of Fiscal Studies.

National Women's Institute (2017), "Mujeres en cifras", Boletín, No. 3.

OECD (Organization for Economic Cooperation and Development) (2017), Building an Inclusive México: Policies and Good Governance for Gender Equality, Paris. (2011), OECD Economic Surveys: Mexico 2011, Paris.

Park, S. and D. Shin (2005), "Explaining procyclical male-female wage gaps", Economics Letters, vol. 88, No. 2, August.

Piazzalunga D. and M. Di Tomasso (2016), "The increase of the gender wage gap in Italy during the 2008-2012 economic crisis", IZA Discussion Paper, No. 9931, Bonn, Institute of Labor Economics (IZA). 
Popli, G. (2008), "Gender wage discrimination in Mexico: a distributional approach", Sheffield Economic Research Paper series, No. 2008006, Sheffield, University of Sheffield.

Rendón, T. and V. Maldonado (2005), "Evolución reciente del trabajo de hombres y mujeres en México", Comercio Exterior, vol. 55, No. 1, January.

Reyes-Heroles, F. and F. Suárez Dávila (coords.) (2009), La crisis: testimonios y perspectivas, Mexico City, Fondo de Cultura Económica.

Rodríguez, R. and V. Germán-Soto (2021), "Desigualdad salarial por género y ciclo económico en las manufacturas mexicanas", Economía, Teoría y Práctica. Nueva Época, No. 54.

Rojas-Gómez, I. and J. Sotelo Peralta (2003), "La mujer mexicana a través de los años: repercusiones históricas y laborales como factores de empuje en la migración internacional”, La migración de la mujer mexicana migrante: de la emancipación a la equidad de género, bachelor's thesis, Cholula, Universidad de las Américas Puebla (UDLAP).

Rubery, J. (ed.) (1988), Women and Recession, London, Routledge/Kegan Paul.

Sabogal, A. (2012), "Brecha salarial entre hombres y mujeres y ciclo económico en Colombia", Coyuntura Económica: Investigación Económica y Social, vol. XLII, No. 1.

Samuelson, P. and W. Nordhaus (2005), Economics, Eighteenth Edition, Boston, McGraw Hill/Irwin.

Sánchez, F., L. Salas and O. Nupia (2003), "Ciclos económicos y mercado laboral en Colombia 1984-2000: ¿quién gana más, quién pierde más?”, Documento CEDE, No. 13 [online] https://economia.uniandes. edu.co/components/com_booklibrary/ebooks/D2003-13.pdf.

Skoufias, E. and S. Parker (2006), "Job loss and family adjustments in work and schooling during the Mexican peso crisis", Journal of Population Economics, vol. 19, No. 1.

Stephens, M. (2002), "Worker displacement and the added worker effect", Journal of Labor Economics, vol. 20, No. 3, July.

Velázquez Orihuela, D. and J. Vargas Sánchez (2014), "El modelo neoliberal y su efecto en el crecimiento económico: el caso de la economía mexicana", Boletín Científico de las Ciencias Económico Administrativas del ICEA, vol. 3, No. 5, Hidalgo, Autonomous University of the State of Hidalgo.

World Bank (2019), "GDP growth (annual \%) - Mexico" [online] https://data.worldbank.org/indicator/NY.GDP. MKTP.KD.ZG?locations=MX. 